\title{
A dendroecological reconstruction of disturbance in an old-growth Fagus-Abies forest in Slovenia
}

\author{
Thomas A. NAGEL ${ }^{a *}$, Tom LEVANIC ${ }^{\mathrm{b}}$, Jurij DIACI ${ }^{\mathrm{a}}$ \\ ${ }^{a}$ University of Ljubljana, Biotechnical Faculty, Department of Forestry and Renewable Forest Resources, Večna Pot 83, 1000 Ljubljana, Slovenia \\ ${ }^{\mathrm{b}}$ Slovenian Forestry Institute, Večna Pot 2, 1000 Ljubljana, Slovenia
}

(Received 24 November 2006; accepted 28 March 2007)

\begin{abstract}
The scarcity of large old-growth forests has made it challenging to quantify disturbance regimes in Central Europe. The objective of this study was to reconstruct the history of disturbance in an old-growth Fagus-Abies forest reserve in Slovenia using a dendroecological approach. We extracted cores from canopy trees blown down during a recent windthrow event and identified growth releases in the tree-ring series using boundary-line release criteria to infer past disturbances. A total of 216 release events were identified from 88 trees. Between 1790 and 1990 , moderate, asynchronous release events were present in nearly every decade of the disturbance chronology, suggesting a history of frequent, low severity disturbance. However, there were also peaks in the chronology corresponding to synchronous release events in a large proportion of the trees, suggesting that less frequent, intermediate severity disturbance events played an important role in forest development. These events are likely caused from wind damage associated with local thunderstorms, which seem to occur at intervals between 20-80 years on the study site. Thus, in addition to the small-scale gap phase processes operating in the forest, the results indicate that periodic intermediate severity disturbance events are an important component of the disturbance regime in mountain forests of Central Europe.
\end{abstract}

dendroecology / forest dynamics / Fagus sylvatica / Abies alba / forest development

Résumé - Reconstruction dendroécologique des perturbations dans une hêtraie sapinière ancienne en Slovénie. Le faible nombre de forêts anciennes suffisamment étendues rend difficile la quantification des régimes de perturbation en Europe centrale. L'objectif de cette étude est de reconstituer l'histoire de ces perturbations dans une hêtraie-sapinière ancienne mise en réserve en Slovénie en utilisant une approche dendroécologique. Des carottes ont été extraites du tronc d'arbres dominants renversés lors d'un récent chablis. Les séries temporelles de cernes ont été analysées pour identifier des périodes de relâchement de contraintes de croissance et pour en déduire l'intensité des perturbations passées. Un total de 216 évènements de relâchement de contrainte a été identifié pour 88 arbres. Entre 1790 et 1990, des évènements d'intensité modérée et asynchrones ont été détectés dans les séries chronologiques au cours de pratiquement toutes les décennies. Cela suggère une fréquence élevée de perturbations de faible intensité. Cependant, des pics d'enregistrement d'évènements synchrones ont été identifiés dans la chronologie dans une proportion importante d'arbres. Cela suggère que des perturbations de sévérité intermédiaire ont joué un rôle important dans le développement de la forêt, malgré leur plus faible fréquence. Ces évènements ont probablement été causés par des chablis provoqués par des orages locaux violents, qui semblent se produire à des intervalles de 20 à 80 ans sur le site d'étude. Les résultats montrent ainsi qu'en sus de perturbations locales de faible intensité conduisant à la formation de petites trouées, les perturbations périodiques de sévérité intermédiaire constituent une composante importante du régime de perturbations dans les montagnes en Europe centrale.

dendroécologie / dynamique forestière / Fagus sylvatica / Abies alba / développement forestier

\section{INTRODUCTION}

In temperate, old-growth forests of Central Europe, natural disturbance events, such as windstorms or insect outbreaks, have traditionally been underemphasized in conceptual models of forest dynamics. Instead, disturbance was mostly viewed as a continuous, endogenous tree mortality process, where small-sale gap-phase dynamics drive canopy recruitment $[16,19,31]$. This model of forest dynamics was based on early descriptive studies in old-growth remnants, which often used maps of developmental phases based on forest structure to infer stand dynamics $[15,18,24,25]$. These studies, however, were supported by little to no tree age data and did not take advantage of the dendroecological techniques available today, making it difficult to understand the complexity of the processes leading to a particular forest structure and composi-

\footnotetext{
* Corresponding author: tom.nagel@bf.uni-lj.si
}

tion. It is well established that annual radial growth patterns in tree cores, along with tree age and recruitment data, can provide valuable insights into the frequency and severity of natural disturbance events [22]. Indeed, this type of information is lacking for old-growth stands in Central Europe, making it challenging to quantify disturbance regime components.

More recently, forest ecologists have begun to place more emphasis on studies of disturbance in Central European oldgrowth forests. There have been a number of recent studies on canopy gaps, which have helped identify the disturbance processes that lead to gap formation $[8,28,38,49]$. Large canopy gaps $\left(>1000 \mathrm{~m}^{2}\right)$ with multiple windthrown gap-makers reported in these studies suggest that less frequent, but more intense disturbance events, such as windstorms, may play an important role in creating larger canopy openings. For example, in the Pecka old-growth, beech-fir forest in Slovenia, two strong thunderstorm events in 1983 and 2004 caused 
intermediate damage to the canopy, creating a maze of interconnected canopy gaps up to $1500 \mathrm{~m}^{2}$ in size [27]. The canopy openings formed during the 1983 storm promoted a coarse-grained network of regeneration, which may have longterm consequences on forest structure [28]. In support of this, recent dendroecological studies in similar old-growth, beechfir-spruce and beech dominated stands in Austria and Italy, respectively, found evidence of higher intensity, periodic disturbance events that thinned portions of the canopy in the past [30, 39].

These studies suggest that disturbance regimes in oldgrowth temperate forests of Central Europe may not be as simple as those described in the early literature, and that less frequent, intermediate intensity disturbance events likely played an important role in their development. Certainly, one of the most accurate ways of reconstructing disturbance histories in temperate forests is to use dendroecological techniques based on the identification of abrupt growth releases in tree cores [1, $9,23,32,44]$. Under this approach, synchronous release from many trees in the same stand suggests larger, more intense canopy disturbance occurred in the past, while many asynchronous release events are indicative of small-scale, singletree canopy disturbances [22]. The purpose of this study was to reconstruct the disturbance history of the Pecka forest reserve in Slovenia by identifying abrupt growth releases in tree cores. Understandably, tree coring is often prohibited in Central European old-growth reserves due to their scarcity and small size, as is the case in Slovenia. To overcome this problem, we cored trees that were freshly blown-down during the 2004 summer storm in the reserve. Our specific objectives were (1) to determine if disturbance is episodic or constant over time; and (2) to examine if there is evidence of less frequent, high intensity disturbance events in the past.

\section{MATERIALS AND METHODS}

\subsection{Study area}

This study was conducted in the Pecka forest reserve, a 60 ha oldgrowth European beech (Fagus sylvatica L.) and silver fir (Abies alba Mill.) forest remnant located on a high karst plateau $(900 \mathrm{~m})$ in the Dinaric Alps, southeastern Slovenia (45 $\left.754^{\prime} \mathrm{N}, 14^{\circ} 995^{\prime} \mathrm{E}\right)$. The karst geology on the site is characterized by abundant sinkholes and limestone outcrops, resulting in a diverse micro-topography. Calcareous brown soils on the site are derived from the limestone parent material, and soil depth can vary between 30 and $70 \mathrm{~cm}$ depending on micro-topographic position. The climate is a combination of continental and Mediterranean, with an annual precipitation of ca. $1400 \mathrm{~mm}$ and mean monthly temperatures between $-4{ }^{\circ} \mathrm{C}$ in January and $20.3{ }^{\circ} \mathrm{C}$ in July.

The forest is dominated by F. sylvatica (81\%) and A. alba (19\%), but also includes less abundant species, such as Norway spruce (Picea abies Karst.), maple (Acer pseudoplatanus L.), and elm (Ulmus glabra Huds.). Fagus sylvatica regeneration is well developed throughout much of the understory, which is primarily the result of increased understory light levels caused by the gradual decline of $A$. alba in the reserve over the second half of the 20th century [34,42]. Regeneration of A. alba has also been substantially reduced by browsing pressure from a large red and roe deer population [6, 7]. Finally, a few scattered $A$. alba in parts of the reserve were selectively cut during the1940s.

\subsection{Data collection and analysis}

Immediately following the windthrow in July, 2004, all canopy layer trees blown down during the storm $(n=70)$ were cored at approx. $1 \mathrm{~m}$. We supplemented these samples with other freshly downed or standing dead trees, which died earlier that year or one year prior $(n=18)$. Trees that died earlier than this were usually too decayed for extraction of intact cores. The cores were mounted and sanded to a high polish following standard dendrochronological procedures [40], and were visually cross-dated by identifying narrow marker years in each tree core [48]. Due to extended periods of very suppressed growth with possible missing rings in the beech cores [33,39], we were unable to successfully cross-date many of these samples. However, because we summarize disturbance by decade, dating errors of one or two years should have little effect on the accuracy of the results. The cores were then digitized and annual radial growth was measured to the nearest $0.01 \mathrm{~mm}$ using WinDENDRO ${ }^{\mathrm{TM}}$ software.

Release events were identified in each core using boundary-line release criteria [2], which provides a standardized approach to release detection. Black and Abrams [2] demonstrate that slow growing trees release more vigorously than fast growing trees, and that the maximum possible value of a pulse in percent-growth-change is dependent on the growth rate immediately prior to the pulse. Moreover, this relationship between release potential and prior growth is species specific and, at least for some species, is consistent across much of its range, so that a universal boundary-line function can be constructed for a species. The boundary-line is then used to scale release events by the maximum possible value predicted by prior growth rate, which allows for direct comparisons of disturbance histories among different stands.

The boundary-line method follows a few simple steps. First, percent-growth change values for each ring in each tree-ring series are calculated according to the running mean technique of Nowacki and Abrams [29]. Under this approach, percent growth change for a year is equal to $\left(M_{2}-M_{1}\right) / M_{1} \times 100$, where $M_{1}$ is equal to average radial growth over the preceding ten year period (inclusive of the disturbance year), and $\mathrm{M}_{2}$ equals average radial growth over the subsequent 10 years (exclusive of the disturbance year). This is followed by calculating prior growth for each year in the tree-ring series, which is simply the average radial growth over the 10 years before the disturbance year. The relationship between percent-growth change and prior growth is then plotted for each year of every tree-ring series, excluding the first and last ten years in each series due to limitations of the formulas. Finally, a boundary line function fitted to the upper threshold of this relationship is quantified.

For this study, we used boundary-line functions recently developed for both $F$. sylvatica and A. alba [39]. The relationship between percent-growth change and prior growth for $F$. sylvatica on our study site fit the F. sylvatica boundary line well, with percentgrowth change pulses that approached the boundary-line. However, our A. alba data failed to reach the previously developed boundaryline at levels of prior growth $>0.3 \mathrm{~mm}$. Black and Abrams [2] also found that some Tsuga canadensis sites did not approach the boundary line developed for this species, and suggested that differences in genotype, site conditions, range position, and disturbance history may account for variation in release response. The previously developed boundary line for A. alba was mainly constructed from chronologies north of our study region, which may explain why our site differed in release response. Consequently, we decided to create a regional boundary-line for $A$. alba using data from this study and chronology data from five other sites located in the Dinaric mountains of 


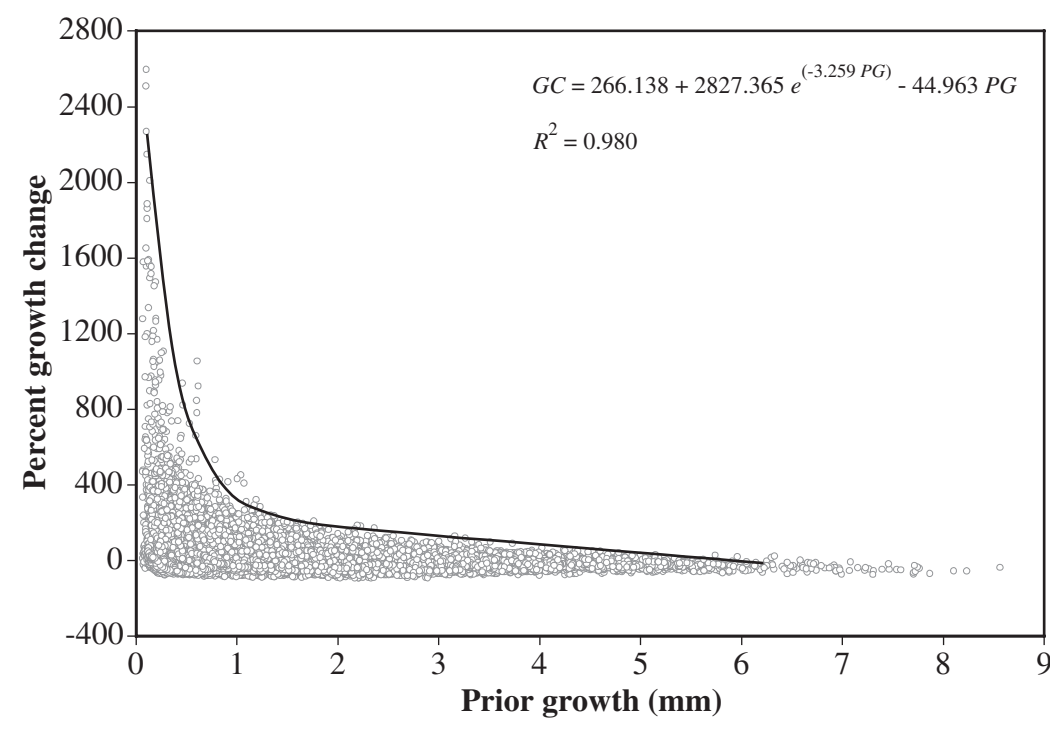

Figure 1. Plot of percent-growth change values (GC) with respect to prior growth (PG) for 33549 A. alba annual growth increments from five sites in Slovenia, showing the regional boundary line.
Slovenia [20,21]. The data set was divided into $0.5 \mathrm{~mm}$ segments of prior growth and the ten highest growth change values in each segment were averaged. However, because there was a steep decline in growth change at low levels of prior growth, we followed the suggestion of Splechtna et al. [39] and divided prior growth up to $1.0 \mathrm{~mm}$ into $0.25 \mathrm{~mm}$ segments. For these segments, only the top five values were averaged. Finally, we fit a modified negative exponential function with an additional linear term to the segment averages. The final boundary line was based on 33549 tree rings (Fig. 1).

The next step of this approach was to scale all the potential release events relative to the boundary line for each species. To do this, we selected the maximum percent-growth change value for each growth pulse identified with the Nowacki and Abrams [29] running mean formula, which should be an accurate estimation of the disturbance year $[29,32]$. The remaining percent-growth change values were dropped from the analysis. Next, percent-growth change values above a particular threshold level were scaled as a fraction of the boundary line by dividing the observed percent-growth change value by the value of the boundary line at a given level of prior growth. Black and Abrams [2] suggest including all percent-growth change values above $10 \%$, while Splechtna et al. [39] only included values above $50 \%$ in their study of disturbance history in an Austrian fir-beech-spruce forest. For this study, we included all percent-growth change values above $25 \%$. After scaling each value with respect to the boundary-line for each analysis, moderate releases were classified as those pulses $>$ $20 \%$ of the boundary-line, and major releases as pulses $>50 \%$ of the boundary-line [2]. Pulses falling below $20 \%$ of the boundary-line were excluded to screen out growth increases caused by climate. Finally, disturbance chronologies were constructed based on the number of cores showing a release each decade.

\section{RESULTS}

From the 88 canopy trees included in the analysis, a total of 386 maximum percent-growth-change values $>25 \%$ were identified with the Nowacki and Abrams [29] running mean formula. After scaling these events relative to the boundary line for each species, 216 qualified as release events, 32 of

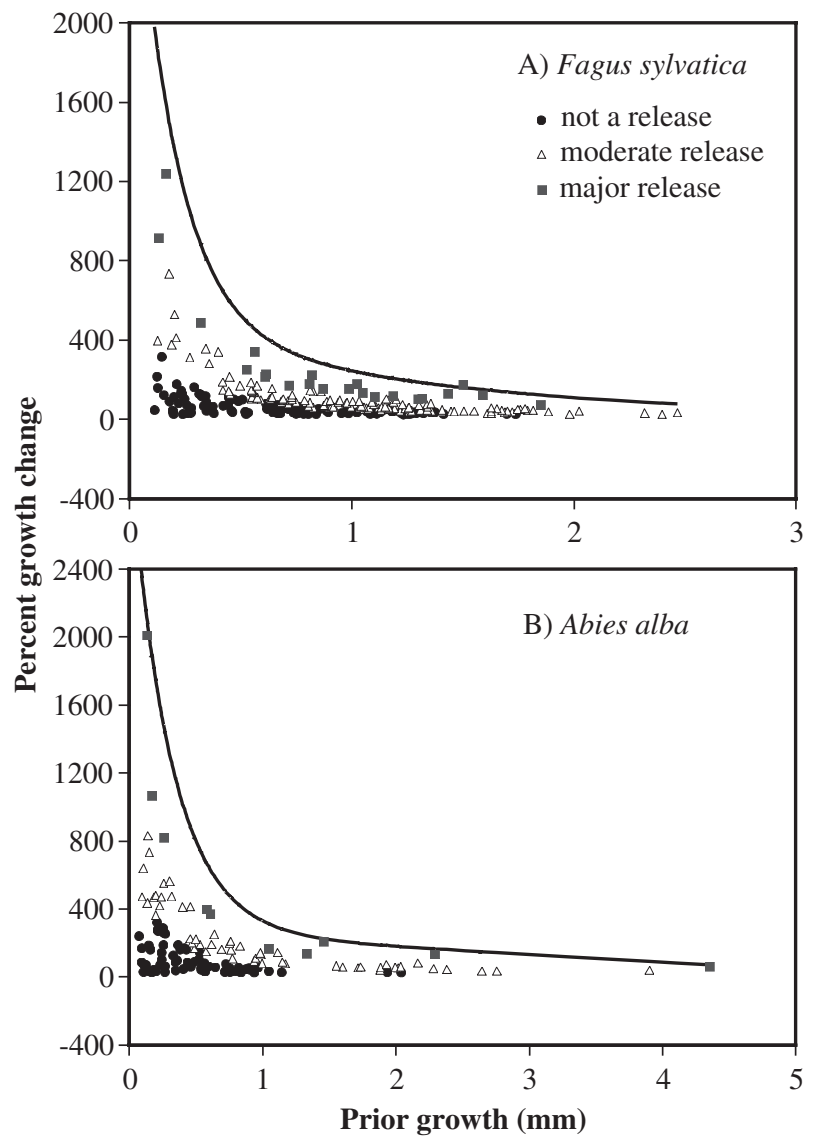

Figure 2. Plot of all maximum percent-growth change values from radial growth pulses $>25 \%$ calculated from the Nowacki and Abrams (1997) formula for F. sylvatica (A) and A. alba (B). Maximum percent-growth change values scaled with respect to the boundary line for each species were classified by major releases (above $50 \%$ of the value of the boundary line) and moderate releases (between 20\% and $50 \%$ of the value of the boundary line). Values less than $20 \%$ of the boundary line were not considered releases. 


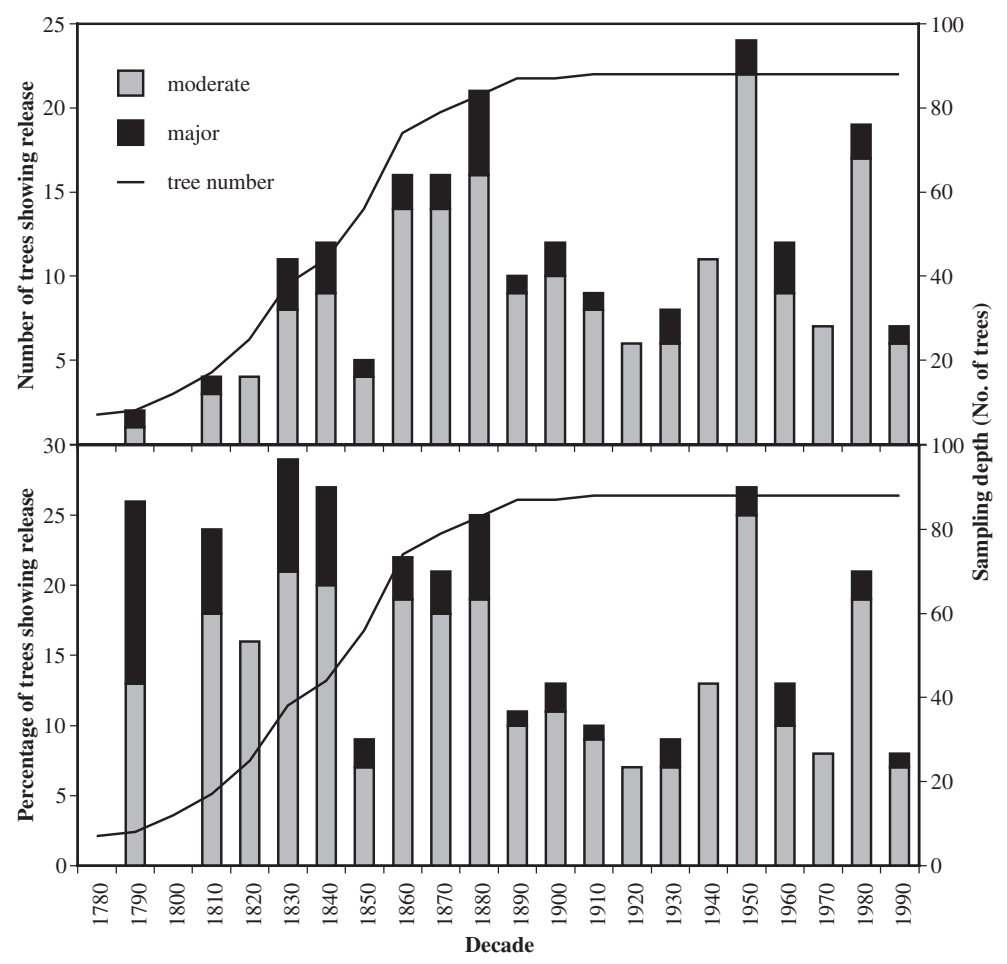

Figure 3. Disturbance chronology from the Pecka old-growth forest reserve showing a decadal distribution of both the total and relative number of major and moderate releases identified with the boundary-line release critera. The sample depth for each decade is indicated by lines.

which were major release events (above 50\% of the value of the boundary line) and 184 of which were moderate releases (between $20 \%$ and $50 \%$ of the value of the boundary line) (Fig. 2). The average number of release events per tree was 2.79 and 2.25 for beech and fir, respectively. The disturbance chronology constructed from the boundary line release events showed that releases occurred in nearly all decades over the last 200 years (Fig. 3). Furthermore, the number of trees showing release each decade varied considerably over the past two centuries, with large peaks in disturbance in the 1980s, 1950s, and 1880s. In the oldest portion of the chronology the number of trees showing release was low, but this was mainly an artifact of the drop in sampling depth after the 1880s. However, the percentage of trees that released each decade was high in many decades during the oldest part of the chronology, especially between the 1790s and 1840s. Moreover, many of the disturbance events in the early part of the chronology were major release events. There were also periods with especially low levels of disturbance. For example, between the 1890s and 1940 s, less than $15 \%$ of trees showed release in each decade.

\section{DISCUSSION}

Moderate release events where present in nearly every decade of the disturbance chronology. In regard to our first research objective, however, disturbances were not constant over time, but varied over the past several hundred years. The relative number of disturbance events was much higher in the 19th century compared to the first half of the 20th century. Furthermore, the older part of the chronology was characterized by more major release events compared to the 20th century. However, it is difficult to determine if the higher percentage of releases in the early portion of the chronology is an artifact of the sampling depth or reflects an increased disturbance rate.

In regard to our second research objective, there were large peaks in the disturbance chronology in several decades, suggesting that moderate to high severity disturbance events occurred episodically in the past several hundred years. For example, before the drop in the chronology sampling depth, large disturbance pulses were found in the 1880s, 1950s, and 1980s. The peak in the 1980s corresponds with a severe storm event that caused widespread damage in the reserve in 1983, blowing down more than 300 canopy layer trees [27], indicating that the boundary line approach is an appropriate method for detecting past disturbance events in our study site. The large peaks in the 1950s and 1880s likely correspond to widespread damage caused by similar severe, local storms in the reserve. We made a thorough examination of all the available historical forest inventory records from the study area spanning the period 1892-1972 [12,13,37], but there were no written accounts of these events. This is likely because prior to the 1980s, forest inventory records from the study area were infrequent and of insufficient detail to record localized damage from infrequent storm events. The only storm event mentioned in the forest records occurred during the 1920 s, which damaged trees in a broader area near the study site, but the specific location could not be determined. 
Contemporary evidence of the 1950s event, such as decayed $\operatorname{logs}$ on the forest floor, was difficult to find in the reserve. This is mainly because Fagus sylvatica logs decompose after about 30-40 years in this region [17], although A. alba logs likely take longer to disappear. We did find old tip and mounds in the area we sampled, as well as highly decayed fir logs. There were also scattered, old gaps present, which were being closed by understory beech trees around $10-20 \mathrm{~cm} \mathrm{dbh}$. However, it is difficult to ascertain the origin of this evidence without further dendroecological studies on live trees, which are not permitted in the reserve. It is also possible that the releases found in the 1950s could correspond to snow or ice damage from a winter storm. These events often cause widespread damage to tree crowns rather than uprooting or snapping entire trees, which could partly explain the lack of structural evidence of a major storm in the 1950s.

It appears from the results of this study that both frequent, low severity disturbances causing small-scale canopy gaps as well as periodic, higher severity events play a role in forest dynamics in our study area. This is in agreement with the widely accepted gap-phase paradigm in Central Europe, but is also in support of dendroecological studies indicating the occurrence of less frequent, moderate to high intensity disturbance events [39,41]. Furthermore, recent canopy gap studies in old-growth F. sylvatica dominated forests in Bosnia-Herzegovina (Nagel and Svoboda, unpublished data), Slovenia [49], Austria [38], and Slovakia [8] documented large canopy openings with multiple windthrown gapmakers. For example, in two old-growth stands studied by Drössler and von Lüpke [8], several gaps greater than 0.4 ha with more than 50 gapmakers, many of which were windthrown, show the importance of strong windstorm events in this region.

This type of wind damage is likely caused by high velocity, localized windbursts associated with strong thunderstorm events. While other disturbance agents, such as insects attacks and heavy snow or ice damage also occur in the mountains of Central Europe, wind accounts for most of the damage in this region [35]. Rather than causing complete, localized canopy destruction, these storm events cause intermediate level damage, characterized by a fine-grained mosaic of canopy damage in a matrix of undisturbed forest, including the creation of intermediate sized canopy openings $\left(>1000 \mathrm{~m}^{2}\right)[4,27,38,47]$. Based on the spatial and temporal scale of this study, it is difficult to determine if these intermediate events occur in a stable manner. In general, it appears that storms of higher than normal intensity occurred at intervals between $20-80$ years over the past 200 years for the study area. The occurrence of frequent thunderstorm events in the study region is also supported by meteorological data $[11,28]$.

These events have important implications on forest development, depending on the stand structure and composition at the time of disturbance, as well as the timing of subsequent disturbances. In an old-growth fir-beech-spruce stand in Austria studied by Splechtna et al. [39], fine-scale neighborhood processes, including gap closure by lateral crown expansion and gradual gap expansion over time, influenced the trajectory of forest development following disturbance. Certainly, the formation of many small to intermediate sized gaps in a

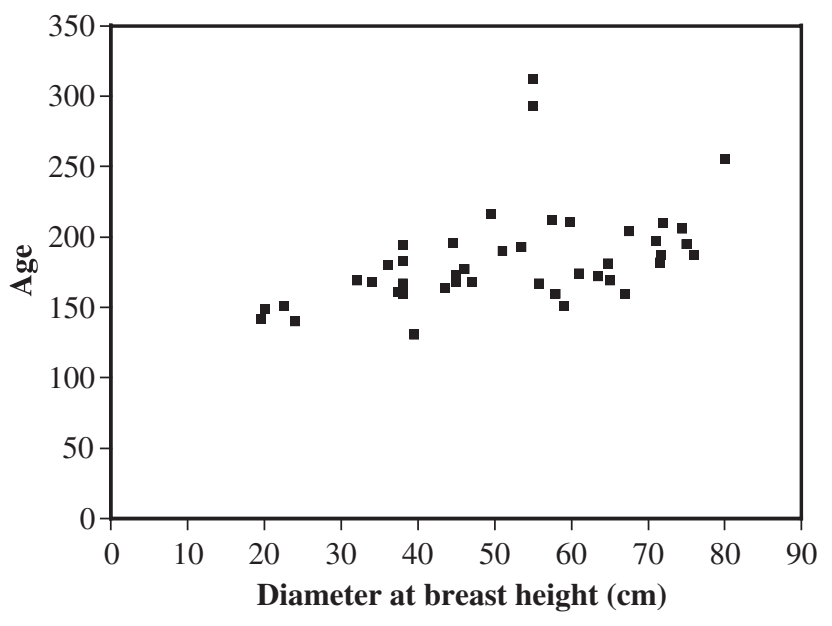

Figure 4. Plot of diameter versus age (at a coring height of $1 \mathrm{~m}$ ) for F. sylvatica trees $>20 \mathrm{~cm}$ dbh. Only cores that reached or were very close to the pith were included. For cores that were close to the pith, the number of missing rings to the pith was estimated based on the average growth rate of the last five visible rings.

forest stand during a storm may lead to increased survival of understory saplings and trees. Subsequent canopy recruitment of these individuals is largely dependent on whether the gaps formed in the storm close or expand. In the Pecka forest reserve, for example, the widespread canopy damage created during the 1983 storm caused major recruitment of advanced regeneration throughout the area of the stand damaged by the storm [28]. The recent storm in 2004 expanded many of the gaps created in the 1983 event, probably because trees bordering larger openings were exposed to winds during the storm [27]. The expansion of these larger gaps will likely lead to formation of broad cohorts of regeneration at intermediate to coarse-scales.

An examination of stand structure alone, such as mapping development phases or measuring diameter distributions, may not provide sufficient information on the complex history of low to intermediate severity disturbances that shape stand development in this region. Defining different development phases in forest stands is difficult, and mapping their boundaries is very subjective, especially in stands with finescale structural heterogeneity, such as the temperate forests in Central Europe. At best, successive mapping of development phases over time can provide useful insight into coarse-scale structural changes $[5,26]$, but at worst they may lead to spurious inferences about the processes that led to a particular forest structure [14]. Similarly, diameter structure data, which have been used to make inferences about forest development in Central European forests [45,46], can also be problematic because of a poor relationship between size and age [22,30,43]. When we examined this relationship for the Fagus trees $>20$ $\mathrm{cm}$ dbh used in this study, a regression analysis showed a week relationship $\left(R^{2}=0.20, p=0.003\right)$ (Fig. 4). Unless a strong relationship between size and age is demonstrated, diameter structure data are of little use in interpreting stand development. We believe that dendroecological data in addition to the 
more traditional approaches that focus on stand structure are needed for a more comprehensive understanding of forest development.

\section{CONCLUSIONS}

Describing disturbance regimes is challenging in Central Europe because of the scarcity of old-growth reference conditions where these processes can be studied. Nevertheless, much attention has been given to applying natural disturbance based processes to silvicultural practices [10,36], especially in regard to unevenaged, "close-to-nature" selection systems in Central Europe [3]. This study provides further support that the disturbance regime in this region is not only characterized by small-scale, endogenous tree mortality processes, but also by intermediate severity windstorm events that likely occur at time scales less than average tree longevity. Silvicultural prescriptions could mimic these events with periodic, higher intensity selective cuts, including the creation of multiple tree gaps. However, if forest managers are to mimic natural disturbance processes in harvesting schemes, a more thorough understanding of the various components of the disturbance regime (i.e. type, frequency, severity, size, etc.) is still needed. We therefore suggest a more multifaceted approach to studying old growth forest development and dynamics in Central Europe. Less emphasis should be placed on describing and mapping developmental phases and more attention should be given to the processes and mechanisms that are responsible for forest development. Dendroecological studies are just one of the approaches that can provide valuable insight into the processes that led to a particular forest structure and composition. In strict forest reserves where tree coring is prohibited, the results of this study show that freshly dead trees can yield valuable material for dendroecological reconstructions of disturbance history.

Acknowledgements: We thank M. Svoboda for assistance in the field. We are also very grateful to B. Black for providing helpful advice and assistance with the boundary line release analysis. Field work was partly supported by a Fulbright grant.

\section{REFERENCES}

[1] Abrams M.D., Orwig D.A., A 300-year history of disturbance and canopy recruitment for co-occurring white pine and hemlock on the Allegheny Plateau, USA, J. Ecol. 84 (1996) 353-363.

[2] Black B.A., Abrams M.D., Use of boundary-line growth patterns as a basis for dendroecological release criteria, Ecol. Appl. 13 (2003) 1733-1749.

[3] Brang P., Virgin forests as a knowledge source for central European silviculture: reality or myth? For. Snow Landsc. Res. 79 (2005) 1932.

[4] Canham C.D., Papaik M.J., Latty E.F., Interspecific variation in susceptibility to windthrow as a function of tree size and storm severity for northern temperate tree species, Can. J. For. Res.-Rev. Can. Rech. For. 31 (2001) 1-10.

[5] Christensen M., Emborg J., Neilsen A.B., The forest cycle of Suserup Skov-revisited and revised, Ecol. Bull. 52 (2007) 33-42.
[6] Debeljak M., Jelka (Abies alba Mill.) v pomladku pragozda Pecka $\mathrm{v}$ zadnjih tridesetih letih (Silver fir in the new growth of the Pecka virgin forest in the last thirty years), Zb. Gozd. Lesar. 53 (1997) $29-48$.

[7] Diaci J., Boncina A., Aktuelle Forschungsergebnisse zur natürlichen Verjüngung in bergwäldern Sloweniens, FBVA Ber. 130 (2003) 57-65.

[8] Drösser L., von Lüpke B., Canopy gaps in two virgin beech forest reserves in Slovakia, J. For. Sci. 51 (2005) 446-457.

[9] Frelich L.E., Lorimer C.G., Natural disturbance regimes in hemlock hardwood forests of the upper great-lakes region, Ecol. Monogr. 61 (1991) 145-164.

[10] Harvey B., Abstracts of the conference on Natural disturbancebased silviculture: Managing for complexity, Rouyn-Noranda, QC, Canada, 2006.

[11] Hocevar A., Petkovsek Z., Meteorologija, Ljubljana, 1984.

[12] Hufnagl L., Wirtschaftsplan der Betriebsklasse 1, Göttenitzer Gebirge, Kocevje, 1892.

[13] Komel L., Gospodarski nacrt za gozdno-gospodarsko enoto Soteska (1963-1972), Ljubljana, 1968.

[14] Konecnik K., Zaplotnik V., Virgin forest reserve Strmec-Research on natural forest structures and comparison of selected methods, Department of Forestry, University of Ljubljana, Ljubljana, 2001, p. 107.

[15] Korpel S., Degree of equilibrium and dynamical changes of the forest on example of natural forests of Slowakia, Acta Facutatis Forestalis, Zvolen, Czechoslovakia 24 (1982) 9-30.

[16] Korpel S., Die Urwälder der Westkarpaten, Gustav Fischer Verlag, Stuttgart, Jena, New York, 1995.

[17] Kraigher H., Jurc D., Kalan P., Kutnar L., Levanic T., Rupel M., Smolej I., Beech coarse woody debris characteristics in two virgin forest reserves in southern Slovenia, Zb. Gozd. Lesar. 69 (2002) 91134.

[18] Leibundgut H., Über Zweck und Methodik der Struktur und Zuwachsanalyse von Urwäldern, Schweiz. Z. Forstwes. 110 (1959) $111-124$.

[19] Leibundgut H., Europäische Urwälder der Bergstufe, Haupt, Bern, 1987.

[20] Levanic T., Growth depression of silver fir (Abies alba Mill.) in the Dinaric phytogeographic region between 1960-1995, Zb. Gozd. Lesar. 52 (1997) 137-164.

[21] Levanic T., Èufar K., Comparison of standard chronologies of silver fir (Abies alba Mill.) in Dinaric phytogeografical region in Slovenia, Zb. Gozd. Lesar. 46 (1995) 131-144.

[22] Lorimer C.G., Methodological considerations in the analysis of forest disturbance history, Can. J. For. Res.-Rev. Can. Rech. For. 15 (1985) 200-213.

[23] Lorimer C.G., Frelich L.E., A methodology for estimating canopy disturbance frequency and intensity in dense temperate forests, Can. J. For. Res.-Rev. Can. Rech. For. 19 (1989) 651-663.

[24] Mayer H., Neumann M., Struktureller und entwicklungsdynamischer Vergleich der Fichten-Tannen-Buchen-Urwälder RothwaldNiederösterreich und Corkova Uvala-Kroatien, Forstw. Cbl 100 (1981) 111-132.

[25] Mayer H., Zukrigl K., Schrempf W., Schlager G., Urwaldreste, Naturwaldreservate und schützenswerte Naturwälder in Österreich, Institut für Waldbau, Universität für Bodenkultur, Wien, 1989.

[26] Mocilnikar H., Regeneration dynamics of the old-growth forest remnant Rajhenavski Rog, Department of Forestry, University of Ljubljana, Ljubljana, 2006, p. 75.

[27] Nagel T.A., Diaci J., Intermediate wind disturbance in an oldgrowth beech-fir forest in southeastern Slovenia, Can. J. For. Res.Rev. Can. Rech. For. 36 (2006) 629-638. 
[28] Nagel T.A., Svoboda M., Diaci J., Regeneration patterns after intermediate wind disturbance in an old-growth Fagus-Abies forest in southeastern Slovenia, For. Ecol. Manage. 226 (2006) 268-278.

[29] Nowacki G.J., Abrams M.D., Radial-growth averaging criteria for reconstructing disturbance histories from presettlement-origin oaks, Ecol. Monogr. 67 (1997) 225-249.

[30] Piovesan G., Di Filippo A., Alessandrini A., Biondi F., Schirone B., Structure, dynamics and dendroecology of an old-growth Fagus forest in the Apennines, J. Veg. Sci. 16 (2005) 13-28.

[31] Prusa E., Die böhmischen und mährischen Urwälder - ihre Struktur und Ökologie, Verlag der Tschechoslowakischen Akademie der Wissenschaften, Praga, 1985.

[32] Rentch J.S., Fajvan M.A., Hicks R.R., Spatial and temporal disturbance characteristics of oak-dominated old-growth stands in the central hardwood forest region, For. Sci. 49 (2003) 778-789.

[33] Rozas V., Tree age estimates in Fagus sylvatica and Quercus robur: testing previous and improved methods, Plant Ecol. 167 (2003) 193-212.

[34] Rozenbergar D., Razvojne znacilnosti sestojev v pragozdnih ostankih Pecka in Rajhenavski Rog (Stand dynamics of the virgin forest remnants of Pecka and Rajhenavski Rog), Gozd. Vestn. 58 (2000) 53-55 (in Slovenian).

[35] Schelhaas M.J., Nabuurs G.J., Schuck A., Natural disturbances in the European forests in the 19th and 20th centuries, Glob. Change Biol. 9 (2003) 1620-1633.

[36] Schutz J.P., Uneven-aged silviculture: tradition and practices, Forestry 75 (2002) 327-328.

[37] Sivic A., Gospodarska osnova za gozdove grascin Soteska, Zuzemberk in Visnja gora, Novo mesto, 1930.

[38] Splechtna B.E., Gratzer G., Natural disturbances in Central European forests: approaches and preliminary results from Rothwald, Austria, For. Snow Landsc. Res. 79 (2005) 57-67.
[39] Splechtna B.E., Gratzer G., Black B.A., Disturbance history of a European old-growth mixed-species forest - A spatial dendroecological analysis, J. Veg. Sci. 16 (2005) 511-522.

[40] Stokes M.A., Smiley T.L., An introduction to tree-ring dating, University of Chicago Press, Chicago, IL, USA, 1968.

[41] Szwagrzyk J., Szewczyk J., Tree mortality and effects of release from competition in an old-growth Fagus-Abies-Picea stand, J. Veg. Sci. 12 (2001) 621-626.

[42] Turk V., Kastelic A., Hartman T., Gozdni rezervati Slovenije: Pragozd Pecka, University of Ljubljana, Biotechnical Faculty, Ljubljana, 1985.

[43] Veblen T.T., Age and size structure of sub-alpine forests in the Colorado front range, Bull. Torrey Bot. Club 113 (1986) 225-240.

[44] Veblen T.T., Hadley K.S., Reid M.S., Rebertus A.J., Blowdown and stand development in a colorado sub-Alpine forest, Can. J. For. Res.-Rev. Can. Rech. For. 19 (1989) 1218-1225.

[45] Von Oheimb G., Westphal C., Tempel H., Hardtle W., Structural pattern of a near-natural beech forest (Fagus sylvatica) (Serrahn, North-east Germany), For. Ecol. Manage. 212 (2005) 253-263.

[46] Westphal C., Trerner N., von Oheimb G., Hansen J., von Gadow K., Hardtle W., Is the reverse J-shaped diameter distribution universally applicable in European virgin beech forests? For. Ecol. Manage. 223 (2006) 75-83.

[47] Woods K.D., Intermediate disturbance in a late-successional hemlock-northern hardwood forest, J. Ecol. 92 (2004) 464-476.

[48] Yamaguchi D.K., A simple method for cross-dating increment cores from living trees, Can. J. For. Res.-Rev. Can. Rech. For. 21 (1991) 414-416.

[49] Zeibig A., Diaci J., Wagner S., Gap disturbance patterns of a Fagus sylvatica virgin forest remnant in the mountain vegetation belt of Slovenia, For. Snow Landsc. Res. 79 (2005) 69-80. 